\title{
Decrease of Morbidity and Cost of Care with Prophylactic Cranial Irradiation for Non-small Cell Lung Cancer
}

\author{
C. E. Champ \\ Thomas Jefferson University Hospitals \\ N. Ohri \\ Thomas Jefferson University Hospitals \\ M. Werner-Wasik \\ Thomas Jefferson University Hospitals
}

Follow this and additional works at: https://jdc.jefferson.edu/bodinejournal

Part of the Oncology Commons

Let us know how access to this document benefits you

\section{Recommended Citation}

Champ, C. E.; Ohri, N.; and Werner-Wasik, M. (2010) "Decrease of Morbidity and Cost of Care with Prophylactic Cranial Irradiation for Non-small Cell Lung Cancer," Bodine Journal: Vol. 3 : Iss. 1 , Article 25. DOI: https://doi.org/10.29046/TBJ.003.1.024

Available at: https://jdc.jefferson.edu/bodinejournal/vol3/iss1/25

This Article is brought to you for free and open access by the Jefferson Digital Commons. The Jefferson Digital Commons is a service of Thomas Jefferson University's Center for Teaching and Learning (CTL). The Commons is a showcase for Jefferson books and journals, peer-reviewed scholarly publications, unique historical collections from the University archives, and teaching tools. The Jefferson Digital Commons allows researchers and interested readers anywhere in the world to learn about and keep up to date with Jefferson scholarship. This article has been accepted for inclusion in Bodine Journal by an authorized administrator of the Jefferson Digital Commons. For more information, please contact: JeffersonDigitalCommons@jefferson.edu. 


\title{
Decrease of Morbidity and Cost of Care with Prophylactic Cranial Irradiation for Non-small Cell Lung Cancer
}

\author{
Champ, C.E., Ohri, N., Werner-Wasik, M.
}

Department of Radiation Oncology, Thomas Jefferson University Hospitals, Philadelphia, PA

\section{Purpose}

While several studies analyze the incidence of brain metastases in patients with non-small cell lung cancer (NSCLC) treated with prophylactic cranial irradiation (PCI), there is little data available on how this treatment can affect medical cost and morbidity. Our goal was to analyze those issues patients encounter secondary to brain metastases, often in the final months of their lives, and to support the hypothesis of economic benefit and cost effectiveness resulting from the use of PCI in this population.

\section{Method and Materials}

We identified 13 consecutive patients with stage III NSCLC, who developed brain metastases at 5-20 months after initial primary tumor diagnosis, with an average of 13.5 months. All patients but four died, at an average of 8 months from diagnosis of brain metastases. We retrospectively analyzed the number of brain MRI and CT scans, hospital visits with length of stay, craniotomies, whole brain radiation and stereotactic radiation for each patient, at our hospital only, with accompanying estimated cost. These numbers were used to assess cost effectiveness and morbidities caused by the exams, surgeries, and hospitalizations.

\section{Results}

Eight patients had craniotomies, with 2 patients undergoing multiple operations. The average number of MRIs was 7 , with one patient having 19. There was an average of $4 \mathrm{CT}$ scans per patient. All patients had brain metastases related hospitalizations, with an average of 13.4 days per patient. All patients received whole brain radiation therapy. Finally, 7 patients received stereotactic radiosurgical boost for their brain lesions, with two receiving multiple treatments. As a result, in the final 8 months of their lives, our patients spent an average of 13 days in the hospital, with over 10 imaging scans performed in this time period, and a median of one craniotomy. During those 8 months, an estimate of minimal cost from our institution (excluding outside hospitalizations) on average was $\$ 57,455$.

\section{Conclusion}

Brain metastases commonly occur in Stage III, NSCLC and cause significant morbidity and financial burden from hospital stays, imaging exams, and surgical interventions. Since RTOG 0214 showed that PCI reduced the incidence of brain metastases in these patients from 18 to $7.7 \%$ at 1 year, if used routinely, it could potentially reduce the cost in this patient population while decreasing morbidity and optimizing resource utilization. 